\title{
Usage Guides, Social Commentary and Views on Education in Late Modern Scotland
}

\begin{abstract}
This contribution discusses two texts published at the height of Late Modern times (Mitchell 1799 and Anon. 1826), in order to trace the roots of well-established labels occurring in assessments of Scottish usage even to this day. ${ }^{1}$ In particular, attention is paid to the qualifiers that the books employ both to stigmatize and to commend forms, so as to outline the kind of ideological stance they conveyed. The two relatively short books are now included in the Corpus of Modern Scottish Writing, and will be presented within the framework of that collection as significant instances of books circulating when linguistic self-consciousness affected both upwardly-mobile speakers and well-educated users. Models of correct usage were found to be useful tools for the acquisition or improvement of both social status and prestige - aims which still resonate with users today and the pragmatic value of which is only just beginning to be explored in a new light.
\end{abstract}

\section{Keywords}

Late Modern (Scottish) English; usage guides; prescriptivism; historical sociolinguistics

\section{Introduction}

Linguistic self-consciousness was quite pervasive in Late Modern Britain, and Scotland was an especially remarkable case. Since the mid-eighteenth century numerous lists of proscribed Scotticisms, elocution and spelling guides, and other self-help materials had circulated both among readers who wished to climb the social ladder and among those whose class and level of schooling might place 
them above such requirements (for instance, the latter category comprised David Hume and James Boswell). This attempt to 'improve' one's language was of course not devoid of ideological undertones also relating to the historical context in which it occurred: Late Modern times dawned with the Union of Parliaments in 1707, and both David Hume's list of Scotticisms (1752) and Johnson's Dictionary (1755) appeared less than a decade after the defeat of the last Jacobite rebellion in 1746, i.e. in years when many publications had a more or less overt loyalist (and unionist) agenda. As the century progressed, attempts to stigmatize socially- and/or geographically-marked forms did not decrease, although commentators stressed the antiquity, distinctiveness, or literary value of Scottish forms; indeed, literature came to be perceived as the only register in which such forms were admitted (see McClure 1995).

In this contribution I intend to present two texts published at the height of Late Modern times (Mitchell 1799 and Anon. 1826), in order to highlight the eighteenth-century roots of labels that would become well-established. In those two case studies I will focus on the qualifiers that the books employ both to stigmatize and to commend forms, so as to outline the kind of ideological stance they conveyed. The two relatively short books (Mitchell 1799 comprises 15,910 words, while Anon. 1826 comprises 55,481) are now included in the Corpus of Modern Scottish Writing, and will be discussed within the framework of that collection as emblematic cases. To that end, the paper will start from an overview of how Scots and Scottish English were perceived, not least on account of a certain ideology of 'improvement'.

\section{A language between idealization and stigmatization}

At the turn of the nineteenth century, Scots was viewed in the light of what McClure (1995: 57) has labelled "the Pinkerton syndrome" - i.e., acceptance as a literary variety and rejection as an everyday medium of expression. This label derives from the fact that in 1786 John Pinkerton published a selection of poetry from the Maitland Manuscripts with the title Ancient Scotish Poems, never before in print, and in the Preface he wrote:

\footnotetext{
None can more sincerely wish a total extinction of the Scotish colloquial dialect than I do, for there are few modern Scoticisms which are not barbarisms [...]. Yet, I believe, no man of either kingdom would wish an extinction of the Scotish dialect in poetry.
}

(Pinkerton 1786: 1/xvii)

As a matter of fact, this dichotomy was not new. While Allan Ramsay's pastoral poems, the success of which preceded those of Robert Fergusson and Robert Burns, presented Scots as a viable literary language, appropriate in its 'Doric' quality to the expression of various emotions, even key figures in the Scottish Enlightenment sought to 'improve' their language, striving to approximate Southern 
English usage. However, language in Scotland had not really been perceived as a significant issue till relatively late in the history of the country. Progressive anglicisation gained momentum in the eighteenth century, after the Union of Parliaments in 1707, which followed the Union of the Crowns by little more than a century.

While it may seem that the importance of 1707 in the history of Scotland's languages has been overemphasised, in fact it increased the prestige of southern accents, as these came to be associated with an ever-growing idea of politeness and thus met the requirements of a pervasive ideology of 'improvement'. Having lost both its court and its political hub, Scotland found itself far from the centres of attraction of 'good society': consequently, upwardly-mobile subjects strove to imitate southern life-styles and modes of expression, in order to gain access to those prestigious circles south of the border.

At the same time, the eighteenth century was also the age of the Scottish Enlightenment, which was distinctively European in its orientation. In McClure's words (1994: 40), "it is something of a paradox that the outstanding literary and intellectual achievements of eighteenth-century Scotland should so clearly manifest an almost pathological confusion, which has never been resolved, in the matter of language, arising from a still deeper confusion regarding the national identity". ${ }^{2}$ Indeed, in 1757 David Hume wrote in a letter to Gilbert Elliot:

Is it not strange that, at a time when we have lost our Princes, our Parliaments, our independent Government, even the presence of our chief Nobility, are unhappy, in our Accent and Pronunciation, speak a very corrupt Dialect of the Tongue which we make use of; is it not strange, I say, that, in these Circumstances, we shou'd really be the People most distinguish'd for Literature in Europe? (Greig 1932, 1: 255)

Within this framework of rigidly evaluative self-consciousness, the regulations that were published in Edinburgh in 1761 by the "Select Society for Promoting the Reading and Speaking of the English Language in Scotland" seem particularly relevant on account of their sociolinguistic focus:

As the intercourse between this part of GREAT BRITAIN and the Capital daily increases, [...], gentlemen educated in SCOTLAND have long been sensible of the disadvantages under which they labour, from their imperfect knowledge of the ENGLISH TONGUE, and the impropriety with which they speak it. (quoted by Jones 1993: 97; my italics)

The Select Society had been established by such prominent figures as Hugh Blair (Professor of Rhetoric and Belles Lettres), ${ }^{3}$ Adam Ferguson (Professor of Natural Philosophy), and William Robertson (principal of the University of Edinburgh and historiographer royal for Scotland), as a follow-up to the elocution lessons that Thomas Sheridan had given to large Edinburgh audiences in 1761. Sheridan's well-known works had, in fact, been preceded (and were to be followed) by numerous works aimed at freeing the expression of Scottish speakers and writers 
of Scotticisms, a term which, according to the OED, had been in use since at least 1648. Nor were women excluded from this market: long before the foundation of the Select Society, in 1719 Scotland saw the foundation of the Fair Intellectual Club for the self-improvement of Edinburgh young ladies (Jones 1997a: 277-278 and 1997b; Aitken 1979: 96), and in 1722 James Robertson published The Ladies Help to Spelling in Glasgow. In the same city, in 1777, what is possibly the first 'pocket dictionary', A Pronouncing Dictionary of the English Language, was published by John Burn.

The sociolinguistic importance of these works appears to be quite prominent and to have explicit political connotations in James Buchanan's Essay towards Establishing a Standard for an Elegant and Uniform Pronunciation of the English Language, throughout the British Dominions as practised by the Most Learned and Polite Speakers (1764). In his Preface he made specific reference to "the inhabitants of North Britain" and connected the acquisition and teaching of "a proper Pronunciation" with "removing national prejudice, which has too long subsisted, and been chiefly fostered between the two kingdoms from their different forms of speech!" According to Buchanan's view, sharing linguistic features was expected to connect England and Scotland "by much more benevolent and generous ties than that of political union" (quoted by Crowley 1991: 79). Beyond the clearly unionist agenda, Buchanan's choice of qualifiers throws considerable light on the perception of variation and its supposed links with social acceptability: pronunciation is expected to be "elegant and uniform", "as practised by the Most Learned and Polite Speakers", which is perhaps somewhat circular, as speakers are deemed to be polite on account of their pronunciation. Indeed, in his previous work, Linguae Britannicae Vera Pronuntiatio, Buchanan had even claimed that: "The people of North Britain seem, in general, to be almost at as great a loss for proper accent and just pronunciation as foreigners" (1757: xv).

The discrepancy between the written and the spoken modes of expression was emphasised by Buchanan (1757: xv) when he found that

\footnotetext{
It would be surprising to find [Scots] writing English in the same manner, and some of them to as great perfection as any native of England, and yet pronouncing after a different, and for the most part unintelligible manner, did we not know, that they never had any proper guide or direction for that purpose.
}

Buchanan (1757: xv) thus stressed the pedagogical (and professionalizing) value of prescriptivism, as he recommended his work to "all whose business is to speak in public, ${ }^{4}$ and all teachers of youth [in North Britain]", so that his readers "be no more distinguished by that rough and uncouth brogue which is so harsh and unpleasant to an English ear."

However, it was not just pronunciation that caused concern. Lexical choices could be just as prominent, and were the object of numerous comments; Tobias Smollett, for instance, thus commented on Francis Home's Experiments on 
Bleaching (1756), also drawing attention to the fact that readers might have difficulty understanding different units of measurement:

The language in some places is a little uncouth. - We meet with some Scottish words and measures, which an English reader will be at a loss to understand. Such as tramp for treading under foot, lint for flax, dreeper for a dripping-stand, bittling for a beetling, mutchkin for a pint, chopin for a quart, Scots pint for two quarts, Scots Gallon for sixteen quarts, etc.

(The Critical Review 1: 114, quoted by Basker 1993: 87)

Concerning vocabulary, one of the most notable works was James Beattie's Scoticisms, arranged in Alphabetical Order, designed to correct Improprieties of Speech and Writing (1779, republished 1787), in which Beattie claimed that "[Scots] are continually afraid of making gross blunders, and when an easy, familiar, idiomatical phrase occurs, dare not adopt it if we recollect no authority, for fear of Scotticisms". Indeed, the correction of Scotticisms as a piece of etiquette had also been perceived by John Sinclair, who, in 1782, had defined the Scots forms as "uncouth, unintelligible, equally conspicuous, at the table, in the pulpit, and at the bar" (cf. Craig 1961: 57). These domains (conversation in polite company and religious and legal discourse) were equally singled out by John Ramsay of Ochtertyre (Craig 1961: 47), who remembered conversing with a member of the Union Parliament who spoke the old 'upper-class Scots'. Ramsay also mentioned that "besides the colloquial Scotch spoken in good company, there was likewise the oratorical, which was used by judges, lawyers and clergymen, [...]." (quoted by Hewitt 1987: 252). ${ }^{5}$ On the other hand, Beattie described this variety as "an affected, mixed, barbarous dialect, which is neither Scotch nor English, but a strange jumble of both" (letter to John Pinkerton of 1778, quoted by Hewitt 1987: 256).

The aspiration to conform to a southern standard of English was important for many educated Scots, with the possible exception of Adam Smith (the author of The Wealth of Nations), who believed that "someone born north of the Tweed could yet attain 'a correct and even elegant style"' (quoted by Rogers 1991: 59). Perhaps notoriously, David Hume was so preoccupied with the standardisation of his written language that he drew up what is possibly the first list of Scotticisms to be avoided: ${ }^{6}$ a list that would form the basis of numerous other publications, often with only minimal adjustments (see Dossena 1997).

It has been argued that in Late Modern times "Scots was rightly considered a different language" (Görlach 1995: 91). However, extensive analysis of texts in which the opinions of intellectuals on linguistic issues are expressed either directly or through their linguistic choices shows that the status of Scots in the eighteenth century was, at best, controversial. From the phonological point of view, a distinct Scottish accent was increasingly perceived to be 'provincial, vulgar, uncouth, conspicuous' (to name but few of the adjectives that were used to describe it). At the same time, as we saw above, a fairly unobtrusive presence of Scots phonological features was the mark of an accepted variety used by the 
upper / professional classes of Scottish society. It was the "tempered medium", "the manly eloquence of the Scotch bar", which, according to James Adams, "affords a singular pleasure to the candid English hearer, and gives merit and dignity to the noble speakers who retain so much of their own dialect". As a matter of fact, Adams' The Pronunciation of the English Language Vindicated (1799: 157, 160 ), from which these remarks are taken, is possibly the most powerful defence of Scottish forms, though it is hardly devoid of ideological overtones itself (see Dossena 2005: 85-90). In addition, Scots could be defended on the grounds of its antiquity. It is an antiquarian interest, for example, that led James Boswell to draft a Scots dictionary nearly half a century before John Jamieson's lexicographic landmark, An Etymological Dictionary of the Scottish Language, of 1808 (see Rennie 2012a). The project, however, was never completed, although even Samuel Johnson had encouraged it, and the manuscript was untraced for nearly two centuries (see Dossena 2005: 73, fn. 37 and Rennie 2011 and 2012b).

Contrasting views on language preservation and 'improvement' were thus powerful forces underlying the ideological stance conveyed in textbooks and usage guides. In the following sections special attention will be given to the avoidance of 'provincial' and 'vulgar' features - i.e., the attempts that were made to overcome geographically- and/or socially-marked traits, especially as far as vocabulary is concerned.

\section{The ideology of improvement and education}

James Beattie's Scoticisms (1779, republished 1787), though prescriptive in its aim, was also descriptive in offering one of the earliest distinctions between overt and covert Scotticisms (Aitken 1992), but lists of proscribed Scotticisms, provincialisms, and vulgarisms continued to be drawn up well into the twentieth century. Glossaries complemented such lists: the Salamanca Corpus provides details of publications concerning Northern, Southern, West and East Midlands varieties of English dating from the seventeenth century to 1950. These were not meant to be actual lexicographic tools, such as John Ray's Collection of English Words Not Generally Used (1674). Rather, they typically presented "peculiar" or "provincial words" and "vulgarisms" pertaining to different areas - for instance, William Humphrey Marshall published Provincialisms of East Norfolk (1787), of East Yorkshire (1788), of the Midland Counties (1790), and of West Devonshire (1796), among other works concerning other regions. In addition, they supplemented humorous dialogues in which dialect was a comic tool, such as in the case of John Collier [aka Tim Bobbin], whose works in the dialect of South Lancashire are among the best-known examples of dialect literature meant for entertainment (see Dossena, under review a). At the turn of the twentieth century stress was still placed on the 'rustic' quality of speech found in provincial areas, and particularly as witnessed in the language of older speakers. Among these, the collections presented by James Wilson meant to illustrate "the homely pithy speech of the 
village folk" (1915: 4) with lists of lexical items, notes on grammar and phonology, riddles, rhymes and songs - see also Wilson (1923 and 1926).

The identification of local forms with humorous usage is at the basis of much 'stage Scots' and other instances found in dialect literature, in which geographically-marked items were typically associated with elderly and/or minimallyeducated speakers. As a matter of fact, the role of education in linguistic promotion was significant, according to the prefaces of numerous schoolbooks. In Late Modern times, and especially throughout the nineteenth century, the importance attached to education, self-improvement, and 'useful knowledge' was pervasive. The Society for the Diffusion of Useful Knowledge was established as early as $1826,{ }^{7}$ and in Victorian times education relied extensively on a variety of institutions, such as parish and church schools, and even the so-called 'ragged schools', as it was not till 1880 that elementary schooling for both boys and girls up to the age of 13 was made compulsory. ${ }^{8}$ In addition, apprentices were expected to get some education; although this was typically minimal, as Anderson (2012: 496) reminds us, "much informal education was available, whether in the Mechanics' Institutes [...], or from radical movements like Chartism and Owenite cooperatives". ${ }^{9}$

As for the materials employed for educational purposes, the avoidance of 'vulgarisms' was of paramount importance on both sides of the Atlantic - see the following examples from American textbooks, ${ }^{10}$ which echo the comments found in their British equivalents:

Mere men of the world, notwithstanding all their politeness, often retain so much of their provincial dialect, $[\ldots]$ as to exclude them from the honour of being the standard of accurate pronunciation. We should perhaps look for this standard, only among those who unite these two characters, and with the correctness and precision of true learning, combine the ease and elegance of genteel life. An attention to such models, and a free intercourse with the polite world, are the best guards against the peculiarities and vulgarisms of provincial dialects.

(Enfield 1803: x)

This here and that there are vulgarisms which should be avoided. (Butler c1846: 144)

The exercises in correcting the erroneous pronunciation of words $[\ldots]$ will tend to remove those vulgarisms so frequently heard in ordinary conversation.

(Town \& Holbrook c1857: 8)

While ideology, description and prescription in American textbooks are discussed elsewhere (Dossena, under review b), in the next sections attention will be paid to Scottish materials. 


\section{Ideology in CMSW}

For the purposes of this study, I chose to investigate texts included in the Corpus of Modern Scottish Writing (CMSW). This corpus comprises over 350 documents, i.e. ca. 5.5 million words of printed texts and manuscript sources from a range of genres and text types: administrative, instructional, religious, imaginative and expository prose, personal writing, verse/drama, journalism, and the writings of orthoepists. While the corpus spans the years 1700-1945, the last category includes the works of Late Modern grammarians, listed in chronological order in Table 1 below. In particular, I selected Mitchell (1799) and Anon. (1826) on account of their more explicitly didactic purpose and of their attempt at overcoming geographical boundaries, while highlighting unique features in the varieties taken into consideration.

Table 1. Late Modern grammarians in CMSW.

\begin{tabular}{|l|l|r|r|}
\hline \multicolumn{1}{|c|}{ Title } & \multicolumn{1}{|c|}{ Author } & Year & $\begin{array}{c}\text { Word } \\
\text { count }\end{array}$ \\
\hline The Only Sure Guide to the English Tongue & William Perry & 1776 & 39,582 \\
\hline Observations on the Scottish Dialect & Sir John Sinclair & 1782 & 22,021 \\
\hline $\begin{array}{l}\text { Two Ancient Scottish Poems: The Gaberlun- } \\
\text { zie Man and Christ's Kirk on the Green, with } \\
\text { Notes and Observations }\end{array}$ & & 1782 & 48,241 \\
\hline Propriety Ascertained in Her Picture, Vol. 1 & James Elphinston & 1786 & 83,998 \\
\hline The Theory of Language in Two Parts & James Beattie & 1788 & 89,062 \\
\hline $\begin{array}{l}\text { Rules to be Observed by the Natives of Scot- } \\
\text { land for Obtaining a Just Pronunciation of } \\
\text { English }\end{array}$ & & 1791 & 3,132 \\
\hline Pronunciation of the English Language & James W. Adams & 1799 & 39,749 \\
\hline $\begin{array}{l}\text { Scotticisms, Vulgar Anglicisms, and Gram- } \\
\text { matical Improprieties Corrected, With Rea- } \\
\text { sons for the Corrections }\end{array}$ & Hugh Mitchell & 1799 & 15,910 \\
\hline The Tyro's Guide to Wisdom and Wealth & Alexander Barrie & 1808 & 58,965 \\
\hline $\begin{array}{l}\text { The Vulgarities of Speech Corrected; With El- } \\
\text { egant Expressions for Provincial and Vulgar } \\
\text { English, Scots and Irish; For the Use of Those } \\
\text { Who Are Unacquainted With Grammar }\end{array}$ & & 1826 & 55,481 \\
\hline $\begin{array}{l}\text { The Dialect of the Southern Counties of Scot- } \\
\text { land }\end{array}$ & Sir James A.H. Murray & 1873 & 118,258 \\
\hline $\begin{array}{l}\text { Critical Inquiry into the Scottish Language } \\
\text { With the View of Illustrating the Rise and Pro- } \\
\text { gress of Civilization in Scotland }\end{array}$ & $\begin{array}{l}\text { Francisque Xavier } \\
\text { Michel }\end{array}$ & 1882 & 117,820 \\
\hline $\begin{array}{l}\text { Lowland Scotch as Spoken in the Lower Strat- } \\
\text { hearn District of Perthshire }\end{array}$ & Sir James Wilson & 1915 & 80,112 \\
\hline The March Hare, No. 3 & Various & 1930 & 10,954 \\
\hline
\end{tabular}




\subsection{Mitchell (1799)}

Mitchell (1799) aims to present a collection of "Scotticisms, Vulgar Anglicisms, and Grammatical Improprieties Corrected, With Reasons for the Corrections [...] Alphabetically arranged, and adapted to the use of Academies, Men of Business, and Private Families". The audience envisaged by the compiler encompasses professional and familiar educators, in addition to 'men of business': i.e., he identifies social categories for which 'appropriate' usage is crucial. Concerning educators, Mitchell also provides methodological suggestions:

To those Teachers who may chuse to introduce this Collection into their Schools, he takes the liberty of recommending the following manner of using it. In the first course, boys might confine themselves entirely to the Scotticisms and Vulgar Anglicisms; and in the last, they might pass over these, and confine themselves entirely to the Grammatical Improprieties. This might be done once or twice every week, without interfering materially with their other Studies. It would be an agreeable and useful variety; and, under the conduct of Skilful Teachers, boys might become tolerable proficients in the course of four and twenty or thirty lessons. (Mitchell 1799: ix)

Nor does the author neglect references to Robert Lowth, Samuel Johnson, "good writers", and the Scripture; for instance, Lowth is cited in relation to methodology, while the Scripture provides grammatical and moral guidance - see the excerpts below:

Bishop Lowth, in the preface to his English Grammar, makes the following excellent observations. "Universal Grammar cannot be taught abstractedly: it must be done with reference to Some Language already known; in which the terms are to be explained, and the rules exemplified. The learner is Supposed to be unacquainted with all, but his native tongue.

(Mitchell 1799: vi*)

There are no words which the Scots are more apt to misapply than shall and will; although it ought to be acknowledged, that, in some instances, the shades of distinction between them are so minute as to be scarcely discernible. [...] The application of shall and will in the third person, is accurately and elegantly illustrated in the following examples from the Scripture: "Whosoever will be great among you, shall be your minister; and "whosoever of you will be the chiefest, shall be "servant of all." "Whosoever will save his life "shall lose it; and whosoever will lose his life for "my sake, shall find it." (Mitchell 1799: 71-72)

Mitchell's attitude to variation, however, allows him to acknowledge 'better' uses when these sound more logical, as in the case of the word 'ink-holder':

Inkhorn is English: yet a silver inkhorn and a golden candle-stick seem to be an abuse of language. Perhaps, in antient times, vessels for holding ink had commonly been made of 
horn. The Scotch term is the better of the two: because, of what materials soever a vessel for holding ink is made, it is very properly called an inkholder. (Mitchell 1799: 47)

Nonetheless, his collection sets out to identify what is "exceptionable, faulty, vulgar, obsolete, improperly used" and of course what is perceived to be a Scotticism; in this respect Mitchell states that he will give special attention to covert Scotticisms, because they are traps into which "even those who have had a liberal education, are sometimes apt to fall", which indirectly suggests their relative viability in daily middle-class usage:

In the department of Scotticisms, he has judged it proper, for obvious reasons, altogether to omit those numberless uncouth Vulgarisms which are peculiar to the lower class of people in Scotland. He has confined himself to such colloquial words and phrases, as prevail among the middle class, and, into which, through inadvertence, even those who have had a liberal education, are sometimes apt to fall. [...] Vulgar words and phrases must be known to be so before they can be avoided; and the Compiler has long been of opinion, that a copious and well selected list of such words and phrases with their corrections, either prefixed or subjoined to English Grammars, would, in this country, be a great improvement. (Mitchell 1799: viii-ix)

Like many other commentators, in the presentation of such features Mitchell relies on humorous anecdotes to make his points memorable (see, for instance, Tieken-Boon van Ostade 1985) - some examples are given below:

When a man does not hear well, the Scotch think it genteel to call him dull rather than deaf. But dull means stupid. Yet "dull of hearing" is English. (Mitchell 1799: 30)

When a stranger, in Scotland, calls on a person upon business, if the person is not at home, the stranger is asked, to leave his name. "Please to leave your name, Sir." In England, the question would be, "Who shall I say was calling, Sir?" Of the two, the Scotch phrase is the more grammatical. An Irish student, at the University of Glasgow, being desired to leave his name, exclaimed, "By -" I cannot do that, "because I may have need of it afterwards." (Mitchell 1799: 50-51)

The coexistence of inappropriate uses in different varieties is thus highlighted, and even an instance of stigmatized American forms is provided:

Was you crying on me? -" Were you calling on me? -" In the former, was you, is Scotch and vulgar English; and crying, a Scotticism. (Mitchell 1799: 29)

He lays in bed; Vulg. Eng. — Lies. — He laid in bed till ten o'clock. — Lay. — These faulty phrases are common in many parts of the Thirteen United States. (Mitchell 1799: 52)

Readers are thus educated and entertained at the same time, following a pedagogic model that both flatters their presupposed competence (they can smile at other users' blunders) while still offering linguistic guidance. 


\subsection{Anon. (1826)}

The full title of this collection is The Vulgarities of Speech Corrected; With Elegant Expressions for Provincial and Vulgar English, Scots, and Irish; For the Use of Those who are Unacquainted with Grammar, and again we find the stated aim to replace what is "vulgar and provincial" with what is "elegant", because, as the quotation attributed to Lord Chesterfield states on the title page, "Vulgar expressions imply either a very low turn of mind, or low education, and low company" (Anon. 1826: titlepage). In addition, readers are informed that the publisher can offer companion volumes on etiquette and a grammar specifically meant for ladies (original capitalization):

Ready for the Press, to be Printed uniformly with this Volume, RULES OF POLITENESS, ETIQUETTE, AND GOOD-BREEDING. Adapted to Modern Fashionable Life, as well as to the Genteel Circles of the Middle Ranks; with an Exposure of the Awkward Manners of the Vulgar Genteel, and an Outline of the Principles of Honour, Insult, and Satisfaction. ALSO, (To be dedicated to the Princess Victoria of Kent, with a Portrait.) THE YOUNG LADY'S GRAMMAR Of the English Language, divested of difficult Terms. On a plan entirely new, and intended to correct Vulgarity, and promote Elegance of Conversation and Writing, by an easy method, for the Use of Governesses and Ladies Schools. (Anon. 1826: colophon)

The promotional blurb concerning The Young Lady's Grammar stresses the link between elegance and proper language, but it is also interesting to note that both that and the present one are due to appear together with a manual on etiquette and good breeding. As a matter of fact, Anon. (1826) opens with remarks on "Vulgar-Genteel Errors, and Affected Speaking", in which hypercorrections are stigmatised:

Country fine-speakers $[\ldots]$ often furnish very strong examples of the vulgar-genteel, $[\ldots]$, as from their limited intercourse with polished society, they usually acquire a stiff, starched, precise way of speaking, and of mouthing and mincing their words, which is exactly the very character of the vulgar-genteel; and extremely different from the easy flow of polite conversation. (Anon. 1826: 8-9)

The book then sets out to correct different types of "vulgarities"; the first of these are labelled "awkward", and concern both syntax and phraseology, as in the examples below:

The first of this class which I shall mention, is a peculiarly awkward manner of bringing in the name of a person at the end of a sentence, with the words "is," "was," or "does," before it. This cannot be described more intelligibly except by an example, such as you may hear every day in all parts of England, as, "he is a worthy man, is Mr. Howard;" instead of saying correctly, "Mr. Howard is a worthy man." (Anon. 1826: 47-48) 
I have some hesitation in mentioning a very awkward species of phraseology which has lately become so common, that perhaps, can scarcely be reckoned vulgar, though stiffness, pedantry, and awkwardness be vulgar, I know not what else it can be called. The awkward phraseology to which I refer has been obviously introduced to avoid the repetition of names, and for the sake of variety; [...]. For example, when Mr. A. is alluded to, he is called that gentleman, instead of using the shorter and more legitimate words "he" or "him". This, however, is not so awkward, as when it is applied to the names of things, as will appear more strikingly by the following extract taken from a Medical Journal: "We have received a very pressing petition from the word "IT," begging that we would interpose our authority to prevent the said "IT" from having its legitimate place usurped in medical language, by the unlawful intrusion of "that," and "this," [...]. Amongst a thousand instances of the usurpation complained of, we find that the brain is called that viscus; the stomach, that bowel; the heart, this organ; the arm, this member; oxygen, that gaseous body; opium, that medicinal; [...].” (Anon. 1826: 52-53)

Vulgarity, however, is not just in affectation: Anon. (1826) also condemns "slovenly vulgarities", such as in abbreviated negative forms and in indistinct pronunciation; he then stigmatizes the overuse of "Bye-Words and Exclamations", e.g. "however," "I see," and "I know," "which are in themselves correct, and excellent when properly employed", [but] "become extremely vulgar as bye-words continually repeated."

As for slang and swearing, it is unsurprising to see that they are labelled as vulgar, but the "Vulgarity of Comparisons, of Proverbs, and Proverbial Expressions" is perhaps less predictable. On the other hand, like in the case of affectation, we find criticism of "Learned, Pedantic, and Professional Vulgarities", "consisting for the most part of favourite words or phrases derived from other languages, of professional terms introduced into common discourse, or of common words pronounced in an uncommon manner." These comments evoke the satirical representation of pedants in Shakespeare's Love's Labours Lost and draw attention to the fact that showing off erudition appears to be as impolite (i.e., 'vulgar') as "Mimickry, Jeering, and Punning, Indelicacy and Coarseness, Wandering and Digression, Egotism, Vulgar Subjects of Conversation [and] Trifling Circumstances". By highlighting such aspects of interaction, Anon. (1826) seems to forerun Grice's Maxim of Relevance (stigmatizing digression - see Grice 1975: 47) and Leech's Politeness Maxims (stigmatizing jeering and egotism - see Leech 1983). The relationship between status and facework (as defined by Brown and Levinson 1987) is also outlined in the following annotation:

Indiscriminate familiarity will either offend your superiors, or make you pass for their dependant; and it will put your inferiors on a troublesome degree of equality with you.

(Anon. 1826: 177)

After such comments on what is (not) appropriate in different social circumstances, the book reverts to "Ungrammatical Vulgarities" pertaining to different geographical areas; we thus have 
- Provincial Scotch Vulgarities, Scotch Accent and Pronunciation, and Scotticisms, such as

Rather go as stay. Annual rent of money. Almost never. Almost nothing. I must cut out my hair. She was married on him.
Rather go than stay. Interest of money. Seldom or never. Little or nothing. I must cut off my hair. She was married to him.

- Provincial Irish Vulgarities, Irish Accent, and Pronunciation, and Irish Idioms, Words, and Expressions, some of which are counted as such, despite their probable Celtic origin ${ }^{11}$ and similarities with Latin - see the quotation below:

Another of the Irish vulgarities of Celtic origin is, that instead of answering a plain question simply by "yes" or "no," part of the question is repeated. For example, if you put the question "does it rain today?" the answer will be "It does" or "It does not," instead of "yes" or "no." If you ask whether the mail has arrived; the answer will be "It has," or "It has not." The words "yes" and "no," indeed, seem to have no place in the Anglo-Irish vocabulary. In this respect, the Latin is somewhat similar. It would, perhaps, be wrong to assert that this manner of answering questions is always a breach of the English idiom, but when it is uniformly practised, it must be considered an Irish vulgarity. (Anon. 1826: 250)

As for "Provincial English Vulgarities, Welsh Vulgarities of Pronunciation, North of England Vulgarities, [and] London Vulgarities of Pronunciation [and of] Expression", these mostly concern well-known phonological shibboleths, such as devoicing in WelshE and voicing in Somerset E., the lack of the foot-strut split in the North, and "in London, and along the South and East coasts, a very gross vulgarity prevails in the sounding of an "r," at the close of words ending in "a" or "o"." Finally, American English is mentioned in relation to 'vulgar abbreviations' and hedges such as "I think":

The most common example, perhaps, of contraction, is that where the word "not" follows "and, are, is, was, were, do, did, have, had, shall, will, should, would, nay, might, can, and could;" [...] what shall we say to the vulgar form which this contraction has now so very commonly taken, and which is so offensive to a grammatical ear? I mean the expression, "a'n't it," which is, I believe, peculiar to England and the United States of America, and is decidedly the most vulgar and incorrect expression in common use. If you have got a habit, therefore, of using this expression a'n't, in any of its applications, you cannot be too careful in avoiding it, as you will never hear it employed by any well educated person, much less by correct or elegant speakers. (Anon. 1826: 22-23) 
We laugh at our American brethren of the United States, for continually repeating, I guess, and I calculate; but we never reflect that our own phrases, I should think so, and In my mind, with many others, are no less unmeaning and vulgar when introduced in the same way. For example, "The mail is not yet arrived, I think; in consequence of the heavy roads, I suppose; and it will be at least, I should think, half an hour later to-day. I should be glad to know why they do not attend to the repairing of the roads, which, in my mind, are disgraceful to the country; that is my opinion." Any person whose conversation is interlarded, almost every time he speaks, with such phrases, may be assured that he can never, while he continues in this habit, speak with elegance or politeness. If we translate this into vulgar American, we shall, perhaps, see its absurdity more strikingly: "The steamer is not yet arrived, I guess, in consequence of some accident, I calculate:" and so of the other phrases. (Anon. 1826: 72-73)

The attention given to the importance of speaking with elegance and avoiding vulgarities places this text at the intersection of etiquette manuals and codifying books, thus drawing attention to the fact that in Late Modern times politeness was not just a matter of pragmatic viability, but also an indispensable social accomplishment - see Paternoster (2019).

\section{Concluding remarks}

The texts discussed in this contribution have shown that the labels attached to language use evaluate phonological aspects, syntactic forms, and lexical or phraseological items. However, that is not all: in many cases they also comment on affectation, egotism, or coarseness - i.e., on traits which, although they are conveyed linguistically, go beyond the kind of competence that can be acquired through mere education. In fact, they relate more to socio-pragmatic acceptability, i.e. to the kind of 'politic behaviour' (Watts 1989) for which books may provide guidance, but which is best learned through 'appropriate interactions'. In a way, 'the company you keep' can be a crucial element in the definition and enhancement of language use, especially for socially-aspiring users who wish to improve their status and therefore need to acquire both language competence and social skills.

Although such concerns may seem outdated in the current world, sociolinguists have pointed out that even present-day publications offer similar recommendations to people who wish to sound educated and for whom the overt prestige of certain varieties is undoubted - see Beal (2009). Moreover, the World Wide Web hosts countless professional and amateur sites in which usage is stigmatized or commended: this does not only concern sites which typically address learners, and whose educational purpose is therefore clear, but also sites and blogs whose readership enjoys sharing (and laughing at) supposed blunders, and even those where humour is less aggressive, though still present, such as when linguistics itself is taken into consideration. ${ }^{12}$

Whether we look at phenomena in a synchronic or a diachronic perspective, the kind of labels discussed in this study sheds light on the importance of social 
and cultural awareness: a concept that is crucial for users, but which is also invaluable for scholars and commentators.

\section{Notes}

1 An earlier version of this paper was presented at the $17^{\text {th }}$ Conference on English Historical Linguistics in Italy (SLIN), held in Ragusa, Italy, on 22-24.10.2015; I am grateful to the organizers and participants for the opportunity to discuss my findings with them. I am also pleased to acknowledge the valuable comments of two anonymous reviewers, while the usual disclaimers apply.

On the other hand, this dichotomy was not perceived by external commentators: Carlo Deanina, for instance, praised the achievements of Scots scholars in various fields, adding that "writing in the same language [as the English], [Scots scholars] suffer not to appear, if we may so express it, to the eyes of other nations, any diminution or decay in the studies of the fine arts." (1763: unnumbered pages).

3 In spite of Hugh Blair's important role, his language did not escape criticism, as Boswell harshly stigmatised his "burring pronunciation and drawling manner with the Lothian tone" (Reed and Pottle 1977: 31).

$4 \quad$ Buchanan obviously refers to clergymen and lawyers, as further on in the text he mentions "excellent and rhetorical speeches delivered by the learned both from the pulpit and at the bar" (1757: xv).

$5 \quad$ This kind of linguistic 'antisyzygy' (or almost paradoxical contrast) is also described in Hume's biography (Hill Burton 1846: 450-451), where the philosopher's "broad Scottish pronunciation" is discussed; according to the editor, "provincial broadness of pronunciation in Scotland is far from being incompatible with a very pure and unprovincial style of language". In a letter to David Mallet of $8^{\text {th }}$ November 1762 Hume defined Scotticisms as "Negligences of Style" and "Vices of Expression" (Greig 1932: 1, 369). Background information is at www.ucl.ac.uk/bloomsbury-project/institutions/sduk.htm, accessed in March 2019. In this respect we should bear in mind that the Scottish system differed from the English one (see Anderson 2012, pace Picard 2009). Among such initiatives we find the one promoted by Andrew Ure (1778-1857), a Scottish chemist, scientific writer and professor at the University of Glasgow; in the same city in 1804 he "inaugurated his series of "Mechanics' Classes" in popular science and its industrial applications for working men, which were, according to the Dictionary of National Biography, [...] probably the first of their kind" (Copeman 1951: 657). The quotations are taken from materials available in the Nietz Collection of Nineteenthcentury Schoolbooks; see also Anderwald (2012). On the Celtic roots of certain features of English syntax, see - most recently - Filppula and Klemola (2014).

12 While offering examples of both EFL websites and of websites making fun of mistakes made by non-native speakers would be too space-consuming, readers may like to be reminded of Speculative Grammarian, a site in which linguists themselves take an ironic look at the tools of their trade (see for instance http://specgram.com/CLXXV.2/05.elves.self3.html, accessed in March 2019). 


\section{References}

\section{Primary sources}

Adams, James (1799) The Pronunciation of the English Language. Edinburgh: Printed for the author by J. Moir.

Anon. (1826) The Vulgarities of Speech Corrected; With Elegant Expressions for Provincial and Vulgar English, Scots and Irish; For the Use of Those Who Are Unacquainted with Grammar. London: Printed for James Bullock.

Beattie, James (1779) Scoticisms, Arranged in Alphabetical Order, Designed to Correct Improprieties of Speech and Writing. Edinburgh: Printed for W. Creech.

Buchanan, James (1757) Linguae Britannicae Vera Pronuntiatio. Reprinted in Alston, R. C. (ed.), English Linguistics 1500-1800, no. 39. London: The Scolar Press, 1968.

Buchanan, James (1764) Essay towards Establishing a Standard for an Elegant and Uniform Pronunciation of the English Language, throughout the British Dominions as practised by the Most Learned and Polite Speakers. London: Printed for Edward and Charles Dilly.

Burn, John (1777) A Pronouncing Dictionary of the English Language. Glasgow.

Butler, Noble (c1846) A Practical Grammar of the English Language. Louisville: John P. Morton \& Co.

Corpus of Modern Scottish Writing, www.scottishcorpus.ac.uk/cmsw/, accessed in Jan. 2019.

Deanina, Carlo (1763) Extract from an Essay on the Progress of Learning among the Scots, [...], Published Lately in the Italian Language, by Carlo Deanina, a Piedmontese. Transmitted in a Letter from Rome, dated February $5^{\text {th }}$, n.p.

Enfield, William (1803) Speaker, or, Miscellaneous pieces: Selected from the Best English Writers and Disposed under Proper Heads, With a View to Facilitate the Improvement of Youth in Reading and Speaking: To which is Prefixed an Essay on Elocution. Baltimore: Printed \& sold by Warner \& Hanna.

Greig, J. Y. T. (ed.) (1932) The Letters of David Hume. Oxford: Clarendon Press.

Hill Burton, John (1846) Life and Correspondence of David Hume. Edinburgh: William Tait

Hume, David (1752) "Scotticisms". In Political Discourses. Edinburgh: Printed by R. Fleming, for A. Kincaid and A. Donaldson, unnumbered pages.

Jamieson, John (1808) An Etymological Dictionary of the Scottish Language. Edinburgh: Printed at the University Press.

Johnson, Samuel (1755). A Dictionary of the English Language. London: Printed by W. Strahan, for J. and P. Knapton; T. and T. Longman; C. Hitch and L. Hawes; A. Millar; and R. and J. Dodsley.

Marshall, William H. (1787) Provincialisms of East Norfolk. The Rural Economy of Norfolk 2, 373-392.

Marshall, William H. (1788) Provincialisms of East Yorkshire. The Rural Economy of Yorkshire 2, 303-366.

Marshall, William H. (1790) Provincialisms of the Midland Counties. The Rural Economy of the Midland Counties 2, 377-389.

Marshall, William H. (1796) Provincialisms of Devonshire. The Rural Economy of the West of England, including Devonshire, and parts of Somersetshire, Dorsetshire, and Cornwall 1, 323-332.

Mitchell, Hugh (1799) Scotticisms, Vulgar Anglicisms, and Grammatical Improprieties Corrected, With Reasons for the Corrections. Glasgow: Printed by Falconer \& Willison.

Pinkerton, John (1786) Ancient Scotish Poems, Never Before in Print. London: Printed for Charles Dilly and William Creech at Edinburgh.

Ray, John (1674) [1691] A Collection of English Words Not Generally Used. London: Printed for Christopher Wilkinson.

Robertson, James (1722) The Ladies Help to Spelling. Glasgow: Printed by James Duncan.

The Nietz Collection of Nineteenth-century Schoolbooks, http://digital.library.pitt.edu/ collection/19th-century-schoolbooks, accessed in Jan. 2019. 
The Salamanca Corpus: Digital Archive of English Dialect Texts, www.thesalamancacorpus.com/ index.html, accessed in March 2019.

Town, Salem and Holbrook, Nelson M. (c1857) The Progressive Third Reader, For Public and Private Schools: Containing the elementary principles of elocution, illustrated by examples and exercises in connection with the tables and rules, and a series of lessons in reading: with original designs and engravings. Boston: Bazin \& Ellsworth.

\section{Secondary sources}

Aitken, A. Jack (1979) Scottish speech: A historical view with special reference to the Standard English of Scotland". In: Aitken, A. Jack and Tom McArthur (eds.) Languages of Scotland. Edinburgh: W. and R. Chambers, 85-118.

Aitken, A. Jack (1992) Scotticism. In: McArthur, Tom (ed.) The Oxford Companion to the English Language. Oxford: Oxford University Press, 900-901.

Anderson, Robert (2012) Learning: Education, class and culture. In: Hewitt, Martin (ed.) The Victorian World. Abingdon: Routledge, 484-499.

Anderwald, Lieselotte (2012) Clumsy, awkward or having a peculiar propriety? Prescriptive judgements and language change in the nineteenth century. Language Sciences 34, 28-53.

Basker, J. G. (1993) Scotticisms and the problem of cultural identity in eighteenth-century Britain. In: Dwyer, John and Richard B. Sher (eds.) Sociability and Society in Eighteenth-Century Scotland. Edinburgh: The Mercat Press, 81-95.

Beal, Joan C. (2009). Three hundred years of prescriptivism (and counting). In: Tieken-Boon van Ostade, Ingrid and Wim van der Wurff (eds.) Current Issues in Late Modern English. Bern: Peter Lang, 35-56.

Brown, Penelope and Levinson, Stephen C. (1987) Politeness: Some Universals in Language Usage. Cambridge: Cambridge University Press.

Copeman, W. S. C. (1951) Andrew Ure, M.D., F.R.S. (1778-1857). Proceedings of the Royal Society of Medicine 44(8), 655-662.

Craig, David (1961) Scottish Literature and the Scottish People 1680-1830. London: Chatto and Windus.

Crowley, Tony (ed.) (1991) Proper English? London: Routledge.

Dossena, Marina (1997) The search for linguistic excellence in eighteenth-century Scotland. Textus 10 (2), 355-376.

Dossena, Marina (2005) Scotticisms in Grammar and Vocabulary. Edinburgh: John Donald (Birlinn).

Dossena, Marina (under review a) Peaceful coexistence? Ideology in the representation of languages and varieties in Late Modern literature. Plenary talk given at the First International Symposium on Approaches to Dialects in English Literature (1500-1950), Salamanca, 26-27 October 2017.

Dossena, Marina (under review b) "Gems of Elocution and Humour": Ideology, prescription and description of American English in nineteenth-century textbooks. Paper presented at the ICEHL workshop on Early American English, Essen 2016.

Filppula, Markku and Klemola, Juhani (2014) Celtic influences in English: A re-evaluation. Neuphilologische Mitteilungen 115 (1), 33-53.

Görlach, Manfred (1995) Dialect lexis in Early Modern English dictionaries. In: Görlach, Manfred (ed.) New Studies in the History of English. Heidelberg: Carl Winter, 82-127.

Grice, H. Paul (1975) Logic and conversation. In: Cole, Peter and Jerry L. Morgan (eds.) Syntax and Semantics 3: Speech Acts. New York: Academic Press, 41-58.

Hewitt, David (1987) James Beattie and the languages of Scotland. In: Carter, Jennifer J. and Joan H. Pittock (eds.) Aberdeen and the Enlightenment. Aberdeen: Aberdeen University Press, 251260. 
Jones, Charles (1993) Scottish Standard English in the late eighteenth century. Transactions of the Philological Society 91 (1), 95-131.

Jones, Charles (1997a) Phonology. In: Jones, Charles (ed.) The Edinburgh History of the Scots Language. Edinburgh: Edinburgh University Press, 267-334.

Jones, Charles (1997b) An early eighteenth century spelling book for ladies. English Studies 78 (5), 430-450.

Leech, Geoffrey (1983) Principles of Pragmatics. London: Longman.

McClure, J. Derrick (1994) English in Scotland. In: Burchfield, Robert (ed.) The Cambridge History of the English Language. Cambridge: Cambridge University Press, 5: 23-93.

McClure, J. Derrick (1995) Scots and its Literature. Amsterdam: John Benjamins.

Paternoster, Annick (2019) Politeness and evaluative adjectives in Italian turn-of-the-century etiquette books (1877-1914). In: Paternoster, Annick and Susan Fitzmaurice (eds.) Politeness in Nineteenth-Century Europe. Amsterdam: John Benjamins, 107-144

Picard, Liza (2009) Education in Victorian Britain. Available at www.bl.uk/learning/histcitizen/ victorians/education/victorianeducation.html, accessed March 2019.

Reed, Joseph W. and Pottle, Frederick A. (eds.) (1977) Boswell: Laird of Auchinleck, 1778-1782. New York: McGraw-Hill.

Rennie, Susan (2011) Boswell's Scottish dictionary rediscovered. Dictionaries: Journal of the Dictionary Society of North America 32, 94-110.

Rennie, Susan (2012a) Boswell's dictionary update. Dictionaries: Journal of the Dictionary Society of North America 33, 205-207.

Rennie, Susan (2012b) Jamieson's Dictionary of Scots: The Story of the First Historical Dictionary of the Scots Language. Oxford: Oxford University Press.

Rogers, Pat (1991) Boswell and the Scotticism. In: Clingham, Greg (ed.) New Light on Boswell. Cambridge: Cambridge University Press, 56-71.

Tieken-Boon van Ostade, Ingrid (1985) "I will be drowned and no man shall save me": The conventional rules for shall and will in eighteenth-century English grammars. English Studies 66 (2), 123-142.

Watts, Richard J. (1989) Relevance and relational work: Linguistic politeness as politic behavior. Multilingua 8 (2-3), 131-166.

Wilson, James (1915) Lowland Scotch as Spoken in the Lower Strathearn District of Perthshire. Oxford: Oxford University Press.

Wilson, James (1923) The Dialect of Robert Burns as Spoken in Central Ayrshire. Oxford: Oxford University Press.

Wilson, James (1926) The Dialects of Central Scotland. Oxford: Oxford University Press.

Marina Dossena is Professor of English Language at the University of Bergamo (Italy). Her main research interests focus on English historical dialectology, especially in relation to Scots and Scottish Standard English, historical pragmatics, and Late Modern English. Her publications include the monograph Scotticisms in Grammar and Vocabulary (Edinburgh: John Donald, 2005), several edited or co-edited collections of essays, journal articles and book chapters. She is currently compiling a corpus of nineteenth-century Scottish correspondence based on previously unedited manuscripts, and participates in a national research project on knowledge dissemination in Late Modern times.

Address: Prof. Marina Dossena, Dipartimento di Lingue, Letterature e Culture Straniere, Università degli Studi di Bergamo, Piazza Rosate 2, 24129 Bergamo, Italy. [marina.dossena@unibg.it] 